\title{
CORPORATE SOCIAL PERFORMANCE AND FINANCIAL PERFORMANCE RELATIONSHIP IN BANKS: SUB-INDUSTRY AND CROSS-CULTURAL PERSPECTIVE
}

\author{
Karolina DASZYŃSKA-ŻYGADŁO ${ }^{\circledR}{ }^{*}$, Tomasz SŁOŃSKI (D, \\ Anna DZIADKOWIEC ${ }^{(D)}$ \\ Department of Corporate and Public Finance, Wrocław University of Economics and Business, \\ Wroctaw, Poland
}

Received 23 February 2020; accepted 6 October 2020

\begin{abstract}
The aim of the paper is to reveal how corporate social performance (CSP) affects market value and earnings capabilities of companies from banking industry: Banking Services and Investment Banking \& Investment Services sub-industries in particular. For Banking Services, the research was extended to a link between corporate social performance and corporate financial performance (CSP-CFP) by classifying institutions into clusters based on a type of culture which dominates in a bank's country of origin. Regression analysis was run on a unique dataset, which comprehensively captures the contextuality of CSP, measured with corporate governance, environmental and social characteristics. This research uses Refinitiv database of ESG Scores as CSP proxy for banks from all over the world in the period of 2009-2016. The results confirm that environmental performance and social performance have negative impact on CFP in banks and partly confirmed that governance performance has a positive impact on their CFP. This research proves that banks' CSP performance and the CSP-CFP relationship differs with regard to the type of bank operations as well as the associated culture. This is an important conclusion for investors seeking to increase value of their holdings and bank management who wants to foster bank's profitability through CSP-related decisions.
\end{abstract}

Keywords: corporate social performance, banking industry performance, financial performance, cultural differences, cross-cultural perspective, Tobin's q, ROA, CSP-CFP link, ESG, social responsibility.

JEL Classification: G21, G32, M14, G34, O44, Z1.

\section{Introduction}

Nowadays, the financial sector reshapes the world's economy and its role is hard to overestimate. According to Shiller (2013), banking industry, as an important part of financial system, supports society in achieving its goals because banks have an ability to stimulate economic growth. Consequently, the better financial institutions adopt to societal needs, the greater

*Corresponding author. E-mail: karolina.zygadlo@ue.wroc.pl 
chance the society will develop (Shiller, 2013). Undoubtedly, the last crisis stigmatized the financial sector and the sector's increasing impact on a number of social activities (so-called financialisation) is perceived as a considerable threat. The academic opponents of financialisation claim (Davis \& Kim, 2015), that this unique combination of financial capitalism theory and ideology forms new patterns of inequality and social change in the society, which translates into changes in corporate strategies and structures. The focus on shareholder value has led to a broad shift in how capital is intermediated through different mechanisms (such as securitization) by financial institutions and other financial market participants.

The recent Corporate Social (CS) efforts of banks are designed to better reflect diverse expectations of stakeholders. In order to measure the impact of CS performance (CSP) on banks' financial performance, we regress financial performance measures (ROA and Tobin's q) over CSP, measured with a widely accepted ESG Scores (formerly ASSET4) published by Refinitiv (formerly Thomson Reuters).

The main purpose of this artcile is to determine if at the current state of banking industry development, banks' sustainability actions align to banks' financial goals in a way which create a single, sustainable whole. Or perhaps, the CS actions are just unavoidable costs one must carry. The novelty of this research lies in the diversity of the data sample, which is ensured by its division into two sub-industries: Banking Services (BS) and Investment Banks \& Investment Services (IB\&IS) as these two groups play a different role in the banking industry and the whole economy. In contrast to other authors, this research uses financial performance measures based on both market and book values over a relatively long period of time, ranging from 2009 to 2016. Moreover, the authors of this research perform their analysis on the sample clustered into cultures to investigate if the CSP-CFP relationship differs with respect to the cluster specifics. This addresses the literature gap related to mediating effects in the CSP-CFP relationship mentioned by Peloza (2009).

The findings of this research have several practical implications. Firstly, they are relevant for investors who seek to identify the impact that a company's CS actions have on its financial performance. Secondly, the results are important for banks' managers who are responsible for increasing a company's value and have a direct impact on CS-related decisions. Thirdly, as the banking industry largely contributes to sustainable development, the research might be useful also for regulatory bodies to identify potential areas where banks might be discouraged to improve its CSP.

The rest of the paper is structured as follows. The next section, reviews the literature related to sustainability in financial sector as well as relevant studies devoted to CSP-CFP relationship. Based on that, the authors develop research hypotheses and show research methods used in existing studies. In the following section, there is a description of the data sample and statistical methods applied in this research. The subsequent section presents the results, which we discuss in the last section and lastly draw final conclusions.

\section{Literature review}

The banking industry has grown in importance and increased its impact on societies in recent years (Cuesta-González et al., 2006; Lauesen, 2013). Due to the banks' large asset size 
and highly diversified investment across regions, industries and asset classes, banks shape economic growth and its direction. Banks play an important role in economic development (Levine, 2005; Beck et al., 2010) as they facilitate cash flow between lenders and borrowers and provide a large stake of financing for companies and governments around the world. In addition, they have unique screening capabilities and therefore, might reduce information asymmetry on financial markets (Cuesta-González et al., 2006). By utilizing its screening capabilities, the banking industry is to some extent responsible for financial stability, which is perceived as a prerequisite for sustainability (EU High-Level Expert Group on Sustainable Finance, 2018). Consequently, in various research it has been noticed that banks take the responsibility not only for direct social and environmental risks they face, but also for indirect impact of the financing they provide (Bouma et al., 2001). Financial institutions have been criticized for their oversimplified understanding of commitment to sustainability, which has been focused on a direct resource consumption. Eccles and Serafeim (2013) suggest that banks could instead focus more on the development of its sustainable offer and encourage customers to buy environmentally-friendly products, green fixed-income instruments, such as green bonds, as well as energy efficient mortgages. With such an approach to CS actions, banks have a huge potential to contribute to sustainable growth by financing socially responsible enterprises, promoting impact investing as well as boosting innovativeness.

It seems, however, that the banking industry has not faced up to its societal responsibilities over the past decades. Interest manipulation, subprime mortgages, and other toxic banking products have adversely affected banks' employee and consumer perception of the industry, even though banks were one of the first to implement Corporate Social Responsibility (CSR) programs to protect their reputation (Soana, 2011). Because of their systemic and societal importance, banks have often been bailed out in times of economic distress or taken over by governments at the expense of taxpayers. Consequently, research shows that the trust in banks has been challenged and has recently been at an all-time low (Hurley, 2014). After the financial crisis of 2007-2008, financial institutions have tried to regain the trust of customers and find new ways to improve their reputation. Corporate Social Responsibility in its various shades seems to be an attractive alternative. Research of Cornett et al. (2013) shows that large banks, widely criticized for the lack of consideration of social aspects in their operations before 2008, improved their CSR activities in recent years. What is more, the transparency of CSR reporting has increased together with the number of financial products that take into account sustainability issues (Scholtens, 2009).

However, financial institutions around the world are not equally willing to engage into CSR practices. There is evidence (Chih et al., 2010) that such factors as the level of selfregulation (e.g. implementation of voluntary policies and frameworks) together with a positive macroeconomic outlook and high quality of managerial education may have a positive impact on the willingness of companies from the financial sector to engage in CSR activities. Moreover, the research of Chih et al. (2010) shows that in countries where investors have strong rights, companies from the financial sector are significantly less willing to implement CSR practices. 


\subsection{Hypothesis development}

A business case shows that sustainability can be managed in order to add value and increase a company's competitiveness (Jensen, 2002; Porter \& Kramer, 2006). In the banking industry, strategic or altruistic approaches to CSR activities enhance brand differentiation, provided that CSR is not related to greenwashing (Shen et al., 2016). Research shows that implementation of CSR practices in the banking industry pays off in the environment of intensive competitiveness (Chih et al., 2010). As a result, banks can seek not only to regain the trust in society and decrease the risk of operations, but also to foster their financial performance through sustainability performance (Bohas \& Poussing, 2016; Michelon et al., 2013).

There is a number of scientific theories that seek to capture the value-creation potential of implementation and disclosure of sustainable practices (Garriga \& Melé, 2004). According to good management theory (Waddock \& Graves, 1997), if stakeholders perceive a company to have a good CSP, it will lead to an improvement of the company's reputation among its main stakeholders. In turn, the company will find it easier to achieve better CFP. This is in line with stakeholder theory (Freeman, 1984), according to which when a company aligns its interests and expectations to the interest and expectations of its stakeholders, agency conflict is reduced. In case of expectations regarding CSP, good CSP could lead to better CFP.

For decades, authors of empirical studies on the CSP-CFP relationship have tried to verify theoretical concepts related to this research problem. According to some of them (Preston \& O’Bannon, 1997; Al-Tuwaijri et al., 2004; Erhemjamts et al., 2013), CSP has a positive impact on CFP but there are also studies (Peng \& Yang, 2014) that confirm a negative relation between these two metrics. In some research (Alexander \& Buchholz, 1978; Aupperle et al., 1985; McWilliams \& Siegel, 2000), no relationship between CSP and CFP has been identified. An extensive meta-analysis of the existing studies (Friede et al., 2015) revealed, that no single sustainability pillar (environmental, social, governance) demonstrates a meaningful superior positive relation to CFP. At the same time, environmental and governance performance exhibit a slightly more positive relation than social performance. McWilliams and Siegel (2000), Rowley and Berman (2000) as well as Elsayed and Paton (2005) point to numerous biases and problems in the existing work, which lead to inconclusive results. The reasons encompass: model misspecification, omitted variables in the determinants of profitability, limited data (small samples, old periods), cross-sectional analysis invalid in the presence of significant firm heterogeneity, problems of measurement of CSR, and the wide diversity of measures used to assess financial performance.

Even though the literature dedicated to CSP-CFP relationship is quite well developed (Friede et al., 2015; Galant \& Cadez, 2017), the number of studies on the banking industry is still limited and largely focused on selected markets (Soana, 2011; Cornett et al., 2013; Fijałkowska et al., 2018; Shakil et al., 2019; Siueia et al., 2019; Ramzan et al., 2021). Existing studies conducted on international samples are still scarce and many of them examine banks' pre-crisis results (Shen et al., 2016). The most recent findings come from the research of Esteban-Sanchez et al. (2017), Gonenc and Scholtens (2019). The former authors found out that banks' governance has a positive impact on CFP, which might be attributable to the reduction of agency problems and better relationships with stakeholders. The findings also 
implicate that positive relations with employees enhance banks' financial performance, as an aftermath of employees' greater commitment, whereas increased product responsibility and better relations with a community have neutral or even negative impact on CFP. In contrast, Simpson and Kohers (2002) found a positive CSP-CFP link in commercial banks. Besides the studies focused solely on the impact of corporate governance and social issues, some authors have analyzed the impact of environmental activities on CFP in financial sector, finding it to be negative (Jo et al., 2014). There is also some evidence that there is a causality relation between CSP and CFP in banks (Laguir et al., 2018), which holds also for other industries (Nelling \& Webb, 2009; Waddock \& Graves, 1997). The results of Gonenc and Scholtens (2019) suggest that financial performance affects banks' responsibility and not the other way round. At the same time, the authors concluded that banks' responsibility is particularly strongly driven by banks' capital adequacy. Other research shows that banks, which engage in CSR activities report not only higher operating ratios but also a lower share of non-performing loans (Shen et al., 2016).

This study expands the existing literature on CSP-CFP relationship in the banking industry. Due to their different characteristics as well as social and economic impacts, we investigate the CSP-CFP relationship in Banking Services (BS) and Investment Banks \& Investment Services (IB\&IS) separately, which is also novel in the literature. Based on the literature review, the following research hypotheses have been verified:

H1: Environmental performance has a negative impact on CFP in BS and IB\&IS.

$\mathrm{H} 2$ : Social performance has a negative impact on CFP in BS and IB\&IS.

H3: Governance performance has a positive impact on CFP in BS and IB\&IS.

According to Hofstede (2011), "Culture is the collective programming of the mind that distinguishes the members of one group or category of people from others". Cultural considerations became an important part of organizational research (e.g. Hofstede, 1983), which indicated a number of interconnection between national culture and managerial decisions. It is now widely recognized that due to divergent cultural conditions, stakeholders' expectations related to corporate decision vary across different countries. National culture determines, among others, how companies interpret and respond to strategic issues (Schneider \& Meyer, 1991), how they establish accounting systems (Zyznarska-Dworczak, 2018), how they approach risk taking (Kreiser et al., 2010) and on top of that, how they engage into and disclose their corporate social responsibility. The impact of culture on the latter was confirmed in a number of studies (Ringov \& Zollo, 2007; Peng et al., 2014; Ortas et al., 2015; Thanetsunthorn, 2015; Halkos \& Skouloudis, 2017; Gallén \& Peraita, 2017; Adnan et al., 2018).

At the same time, literature that focuses on the relationship between CSP and CFP in different cultures is not well developed. The findings of Miras-Rodriguez et al. (2015) suggest that there might be some differences in the aforementioned relationship across cultures. The authors identified that in cultures characterized by high assertiveness and gender egalitarianism the CSP-CFP relationship is negative, whereas in countries with high future orientation, institutional collectivism and humane orientation, the relationship is positive. Due to the limited research on the role of culture on the CSP-CFP relationship in banking industry, one may conclude on this matter based on regional studies. A positive relationship was identified between CSP and CFP banks in the U.S. (Cornett et al., 2013), whereas Soana (2011) 
and Fijałkowska et al. (2018) found no significant impact of CSP on CFP in Italy and CEEC region, respectively. In case of Islamic banks, CSR disclosures prove to have positive impact on CFP (Mallin et al., 2014), from management and shareholders' perspective in particular (Jan et al., 2019).

This study fills in the gap related to mediating effects in the CSP-CFP relationship in banks as it controls for various cultural backgrounds of the countries the banks originate from. Based on literature review, the following hypothesis related to culture have been developed:

H4: The CSP-CFP relationship in banks from BS sub-industry differs with respect to their cultural affiliation.

\subsection{Review of research methods}

Different methodologies have been used to analyze the CSP-CFP relationship. According to a comprehensive review of up-to-date studies in the field (Galant \& Cadez, 2017), one of the most commonly-used methods is the immediate effect analysis applied in event studies. Over past decades, CSR has become an important part of investment strategies on capital markets. Therefore, scientists started to examine if unexpected events related to changes in CSR or environmental or social scandals are somehow reflected in the financial performance measured by stock performance. The examples of such include CEO successions, death of a key executive, customer services changes, layoff programs or discrimination suits (McWilliams \& Siegel, 2000). With the development of sustainability indices, other studies have shown how investors react when a company is included (excluded) in (from) sustainability index (Cheung \& Roca, 2013; Consolandi, et al., 2009). One of the advantages of event studies is its ability to track time trends, e.g. Lins et al. (2017) examined, how CSP affected the market performance of companies in the period of the financial crisis 2007-2008.

An alternative approach to event studies measures long-term effects (usually calculated as a yearly effect over a certain period of time) in the CSP-CFP relationship. The companies' financial performance, expressed as accounting- or market-based measures, is regressed over sustainability (or CSR) performance, measured by scoring or rating results (Saeidi et al., 2015; Wang \& Berens, 2015, Daszyńska-Żygadło et al., 2016). Regression analysis is run on panel data structure, which has more dimensions than time-series and cross-sectional data (Hsiao, 2007). Multidimensionality of panel data has the ability to capture the complexity of a problem and, therefore, to reflect the multidimensionality of CS actions. Out of these reasons, regression analysis on panel data has been selected in this study.

\section{Data description and methodology}

\subsection{Data sample}

The dataset used in the research has been retrieved from Refinitiv (formerly Thomson Reuters Datastream). Due to potential strategic and operational differences between banks, the sample has been subdivided into two sub-industries: 1) Banking Services (BS) and 2) Investment Banking and Investment Service (IB\&IS), according to Thomson Reuters Business 
Classification (TRBC). The unbalanced data panel used in the research sample covers 2693 and 931 observations in the group of BS and IB\&IS, respectively. Banks in the sample are registered in both Americas, Europe, Middle East and Africa and Asia Pacific.

In order to improve a way of differentiating companies in the sample and contribute to the existing literature in that matter, we assigned a culture to each bank based on the Global Leadership and Organizational Behavior Effectiveness (GLOBE) Research. The data sample used in the GLOBE Research come from more than seventeen thousand middle managers, whereas the countries were assigned to specific cultures based on nine cultural dimensions. Due to the limited sample size, there are five groups analyzed in this research: Anglo-Saxon Cultures, Confucian Asia, South Asia, Middle East and Continental Europe, which includes Nordic, Latin and Germanic Europe. Because of the sample size, the cultural study has been limited to BS.

\subsection{Variables and statistical methods}

This study examines the CSP-CFP link in banks with market- and accounting-based financial performance measures that are commonly used by bank executives and external investors to evaluate banks' performance. Market-based financial performance measures have been expressed with simplified Tobin's q, because the ratio has a capacity to capture the market value of a firm's goodwill. Companies with a higher Tobin's q have competitive advantages that might result either from such intangibles as brand, reputation, monopolistic position, technological innovations or from CS activities. Capitalization of CS activities results in changes in book value of a firm's assets and influences Tobin's q (Daszyńska-Żygadlo et al., 2016). Tobin's $q$ is also considered to have a long-term impact on the firm's operating performance (Fu et al., 2017). The ratio plays an important role in this analysis because it measures the bank's ability to generate a premium over replacement costs that is measured by the sum of economic value added in a long perspective (Damodaran, 2012). Tobin's q combines the features of accounting- and market-based financial performance measures (Galant \& Cadez, 2017) and has been already used in the studies on CSP-CFP relationship (Garcia-Castro et al., 2010; Rodgers et al., 2013; Daszyńska-Żygadlo et al., 2016).

In addition, financial performance has been measured with return on assets (ROA), which captures one-year, short-term effects of corporate social performance on financial performance and is complementary to Tobin's q. ROA is a more reliable indicator of profitability than return on equity (ROE) in banks because it is less exposed to leverage effects. Empirical studies show that banks with higher level of ROA were more resilient to negative effects of the financial crisis of 2007-2008 (European Central Bank, 2010). Due to the fact that ROA is adjusted for the leverage, the indicator is lower for investment banks and higher for the universal ones. This is an additional rationale for subdivision of the sample of banks into two groups.

In this research, ESG Scores (formerly ASSET4) provided by Refinitiv (formerly Thomson Reuters Datastream) have been used as a proxy for CSP. With more than 6500 public companies evaluated globally and the database's history going back to 2002, ESG Scores serve as a good sustainability reference for banks with regard to regions, cultures and time horizon. 
Moreover, the database ensures transparency and comparability thanks to the manual and standardized data collection process. Information sources range from the ones delivered by companies themselves (annual reports, websites, CSR reports and stock exchange filings) to independent data provided by non-governmental organizations and media. ESG Scores evaluate each sustainability pillar (environment, social and governance). In the environmental context, the following categories are assessed: resource use, emissions and innovations, while in the case of social issues: workforce, human rights, community and product responsibility. Governance Score captures the following aspects: management, shareholders and CSR strategy. ESG Scores have been already used by other authors (Daszyńska-Żygadlo et al., 2016; Esteban-Sanchez et al., 2017; Gonenc \& Scholtens, 2019), who carried out research on the CSP-CFP relationship in the past. However, the uniqueness of this research is ensured by the up-to-date dataset, which covers the period from 2009-2016 and a sample limited specifically to the banking industry. All sustainability pillars have been included in the analysis, which is another contribution to the existing literature.

Several control variables have been included in the models in order to avoid omitted-variable bias. Based on the findings of other authors (Barth et al., 1998), a firm's value depends on its profitability, size and sales growth. In the model measuring financial performance with Tobin's q, all aforementioned variables have been included. ROA has served as a proxy for profitability, while logarithm of market capitalization and one-year revenue growth as the proxy for bank size and sales growth, subsequently. As the year may affect the financial results of banks, the authors have introduced the dummy variables of years. In case of accountingbased financial measures, besides size and sales growth, the authors used a lagged value of the dependent variable as an independent one. The reason is that accounting profitability of the previous period influences the profitability of the present one.

Based on the Ordinary Least Squares regression with Newey-West correction for heteroscedasticity, two models have been estimated (Eqs (1), (2)). The first sample has covered banks from all around the world with subdivision into Banking Services (BS) and Investment Banking and Investment Services (IB\&IS). In the next step, the regression analysis has been run on BS' observations in each of the previously identified cultural groups.

$$
\begin{aligned}
& \text { Tobin's } q=\alpha_{0}+\alpha_{1} \text { Environmental Score }+\alpha_{2} \text { Social Score }+ \\
& \alpha_{3} \text { Corporate Governance Score }+\alpha_{4} \text { ROA }+\alpha_{5} \text { Size }+\alpha_{6} \text { Sales growth }+\sum_{i=1}^{9} \operatorname{Year}_{i}+\varepsilon_{i} ;
\end{aligned}
$$

ROA $=\alpha_{0}+\alpha_{1}$ Environmental Score $+\alpha_{2}$ Social Score +

$\alpha_{3}$ Corporate Governance Score $+\alpha_{4}$ ROA lagged $+\alpha_{5}$ Size $+\alpha_{6}$ Sales growth $+\varepsilon_{i}$.

\section{Results}

\subsection{Descriptive statistics}

CSP of BS and IB\&IS' differs with regard to each CSP pillar (Table 1). Based on the z-test, there is a significant ( $5 \%$ confidence level) difference in means for subsequent CSP pillars 
between 1) BS and IB\&IS as well as 2) cultural subsamples and the sample of BS, with the only exception of the social dimension for Middle East. This means that 1) banks operating in a specific market segment and 2) banks in specific cultures, share distinctive features and have remarkably diversified CSP.

Based on descriptive statistics one can see that banks' CSP in subsequent pillars differs with regard to the associated cultural background. This supports the direction of this research aimed at finding out whether cultural background of the bank plays a role in the CSP-CFP relationship (the hypothesis $\mathrm{H} 4$ ).

Table 1. Descriptive statistics for each CSP pillar

\begin{tabular}{|c|c|c|c|c|c|c|c|}
\hline & \multirow{2}{*}{$\begin{array}{l}\text { Banking } \\
\text { Services }\end{array}$} & \multirow{2}{*}{$\begin{array}{c}\text { Investment } \\
\text { Banking \& } \\
\text { Investment } \\
\text { Services }\end{array}$} & \multicolumn{5}{|c|}{ Cultural group (Banking Services only) } \\
\hline & & & $\begin{array}{l}\text { Anglo- } \\
\text { Saxon }\end{array}$ & $\begin{array}{c}\text { Continental } \\
\text { Europe }\end{array}$ & $\begin{array}{l}\text { Middle } \\
\text { East }\end{array}$ & $\begin{array}{c}\text { Confucian } \\
\text { Asia }\end{array}$ & $\begin{array}{l}\text { South } \\
\text { Asia }\end{array}$ \\
\hline $\begin{array}{l}\text { No. of } \\
\text { obser- } \\
\text { vations }\end{array}$ & 2693 & 931 & 960 & 541 & 144 & 536 & 294 \\
\hline & \multicolumn{7}{|c|}{ Environmental Score } \\
\hline Average & 45.7 & 36.7 & 39.5 & 61.9 & 38.0 & 43.2 & 40.7 \\
\hline Median & 34.6 & 21.5 & 14.2 & 78.3 & 20.8 & 33.1 & 33.5 \\
\hline $\operatorname{Max}$ & 95.3 & 94.3 & 95.3 & 95.3 & 94.7 & 94.9 & 93.4 \\
\hline \multirow[t]{2}{*}{ Min } & 8.6 & 8.6 & 8.6 & 8.6 & 9.4 & 8.6 & 9.4 \\
\hline & \multicolumn{7}{|c|}{ Social Score } \\
\hline Average & 48.8 & 41.7 & 42.8 & 65.6 & 46.7 & 40.0 & 51.4 \\
\hline Median & 45.4 & 37.5 & 35.1 & 79.3 & 43.0 & 32.2 & 49.7 \\
\hline Max & 97.7 & 97.5 & 97.7 & 97.5 & 94.8 & 96.0 & 96.7 \\
\hline \multirow[t]{2}{*}{ Min } & 3.6 & 3.5 & 5.0 & 3.6 & 4.2 & 3.9 & 5.5 \\
\hline & \multicolumn{7}{|c|}{ Governance Score } \\
\hline Average & 43.0 & 54.1 & 61.9 & 46.6 & 17.2 & 19.9 & 39.6 \\
\hline Median & 41.9 & 59.1 & 64.5 & 43.7 & 10.6 & 10.6 & 40.7 \\
\hline Max & 97.5 & 97.0 & 97.2 & 97.5 & 62.1 & 90.6 & 90.4 \\
\hline Min & 1.2 & 1.3 & 4.0 & 1.3 & 1.4 & 1.2 & 2.0 \\
\hline
\end{tabular}

\subsection{Regression results}

Table 2 and 3 present regression results for Eqs (1) and (2), respectively with regard to banks' types of operations.

The results indicate that CFP of BS and IB\&IS does not react equally to their CSP. Corporate governance score is significant in both industries and its impact on CFP is positive. In contrast, social performance' is weaker and negative but significant only in the case of BS. Environmental performance does not influence banks' financial performance in BS, whereas for IB\&IS it has a negative and statistically significant impact. 
Table 2. Regression results for Tobin's q - Banking Services (BS) and Investment Banking \& Investment Services (IB\&IS)

\begin{tabular}{|c|c|c|}
\hline Variable & BS & IB\&IS \\
\hline Intercept & $1.2502^{\star * *}$ & 0.1535 \\
\hline ROA & $0.0260^{* * *}$ & $0.1328^{\star \star \star *}$ \\
\hline Size & $(0.0205)^{\star * *}$ & 0.0148 \\
\hline Sales growth & 0.0001 & $(0.0000)^{\star \star}$ \\
\hline year 2009 & 0.0118 & $0.4441^{* * *}$ \\
\hline year 2010 & 0.0913 & 0.2371 \\
\hline year 2011 & $(0.0248)$ & 0.1333 \\
\hline year 2012 & $(0.0280)^{\star}$ & 0.2490 \\
\hline year 2013 & $(0.0071)^{\star}$ & $0.3289^{* *}$ \\
\hline year 2014 & $(0.0197)$ & 0.2962 \\
\hline year 2015 & $(0.0184)$ & 0.2161 \\
\hline year 2016 & 0.0089 & $0.4922^{\star *}$ \\
\hline Environmental score & 0.0001 & $(0.0049)^{\star *}$ \\
\hline Social score & $(0.0008)^{\star \star}$ & $(0.0008)$ \\
\hline Corporate Governance score & $0.0020^{\star \star \star}$ & $0.0098^{\star * *}$ \\
\hline R-squared & 0.1305 & 0.5121 \\
\hline Adjusted R-squared & 0.1259 & 0.5047 \\
\hline
\end{tabular}

Note: ${ }^{\star},{ }^{* \star}$ and ${ }^{\star * \star}$ denote significance levels of $0.1,0.05$ and 0.01 respectively.

As mentioned in the previous section, ROA has a power to explain Tobin's q. In the following model, ROA (which has the direct link to Tobin's q through the book value of assets) serves as a proxy for profitability. In order to improve the goodness of fit of the model, lagged profitability data for both industries have been introduced.

Table 3. Regression results for Tobin's q - Banking Services (BS) and Investment Banking \& Investment Services (IB\&IS)

\begin{tabular}{|l|c|c|}
\hline \multicolumn{1}{|c|}{ Variable } & BS & IB\&IS \\
\hline Intercept & 0.1802 & $(0.2427)$ \\
\hline ROA lagged & $0.7336^{* * *}$ & $0.7422^{* * *}$ \\
\hline Size & 0.0161 & 0.1852 \\
\hline Sales growth & 0.0010 & $(1.040)$ \\
\hline Environmental Score & $(0.0045)^{\star *}$ & $(0.0141)$ \\
\hline Social Score & 0.0018 & $(0.0216)^{*}$ \\
\hline Corporate Governance Score & 0.0016 & 0.0094 \\
\hline R-squared & 0.6105 & 0.5649 \\
\hline Adjusted R-squared & 0.6095 & 0.5619 \\
\hline
\end{tabular}

Note: ${ }^{\star},{ }^{\star \star}$ and ${ }^{\star * \star}$ denote significance levels of $0.1,0.05$ and 0.01 respectively. 
Table 4 and 5 present regression results for Model 1 and 2, respectively with regard to each cultural group associated with banks' origin in BS.

Table 4. Regression results for Tobin's q - cultural groups

\begin{tabular}{|l|c|c|c|c|c|}
\hline \multicolumn{1}{|c|}{ Variable } & Anglo-Saxon & $\begin{array}{c}\text { Continental } \\
\text { Europe }\end{array}$ & Middle East & $\begin{array}{c}\text { Confucian } \\
\text { Asia }\end{array}$ & South Asia \\
\hline Intercept & $1.2878^{* * *}$ & $0.9572^{* * *}$ & 0.1380 & $0.7171^{* * *}$ & $0.9172^{* * *}$ \\
\hline ROA & $0.0459^{* * *}$ & $(0.0057)^{* * *}$ & $(0.0444)$ & $(0.0160)^{* *}$ & $(0.0107)^{\star * *}$ \\
\hline Size & $(0.0223)$ & 0.0028 & $0.0916^{* *}$ & $0.0137^{* * *}$ & 0.0025 \\
\hline Sales growth & $(0.0003)$ & $0.00001^{* *}$ & $(0.0029)$ & $(0.0001)$ & $(0.0002)$ \\
\hline year 2009 & 0.0255 & $(0.0031)$ & $(0.0940)$ & $(0.0059)$ & $(0.0138)$ \\
\hline year 2010 & 0.0937 & $(0.0164)$ & $(0.1427)$ & $(0.0152)$ & $(0.0071)$ \\
\hline year 2011 & $(0.0264)$ & $(0.0285)^{* * *}$ & $(0.1587)$ & $(0.0151)$ & $(0.006)$ \\
\hline year 2012 & $(0.0184)$ & $(0.0277)^{* * *}$ & $(0.1482)$ & $(0.0088)$ & $(0.0073)$ \\
\hline year 2013 & 0.0591 & $(0.0163)$ & $(0.1703)$ & $(0.0124)$ & $(0.0050)$ \\
\hline year 2014 & 0.0314 & $(0.0224)^{* *}$ & $(0.2418)^{*}$ & $(0.0110)$ & $(0.0090)$ \\
\hline year 2015 & 0.0139 & $(0.0324)^{* * *}$ & $(0.1865)$ & $(0.0205)^{*}$ & $(0.0020)$ \\
\hline year 2016 & 0.0278 & $(0.0313)^{* * *}$ & $(0.2095)$ & $(0.0172)$ & $(0.0185)^{*}$ \\
\hline Environmental Score & $0.0016^{* * *}$ & 0.0001 & 0.0001 & $(0.0003)^{* *}$ & $(0.0004)^{* * *}$ \\
\hline Social Score & $(0.0015)$ & $(0.0004)^{* * *}$ & $(0.0052)^{* *}$ & $0.0007^{* * *}$ & 0.0001 \\
\hline $\begin{array}{l}\text { Corporate Gover- } \\
\text { nance Score }\end{array}$ & 0.0008 & $0.0004^{* * *}$ & $(0.0013)$ & $(0.0002)^{* *}$ & $(0.0000)$ \\
\hline R-squared & 0.2083 & 0.1324 & 0.2425 & 0.2287 & 0.4143 \\
\hline Adjusted R-squared & 0.1967 & 0.1094 & 0.1603 & 0.2073 & 0.3849 \\
\hline
\end{tabular}

Note: ${ }^{*},{ }^{* *}$ and ${ }^{* * *}$ denote significance levels of $0.1,0.05$ and 0.01 respectively.

Table 5. Regression results for ROA - cultural groups

\begin{tabular}{|l|c|c|c|c|c|}
\hline \multicolumn{1}{|c|}{ Variable } & Anglo-Saxon & $\begin{array}{c}\text { Continental } \\
\text { Europe }\end{array}$ & Middle East & $\begin{array}{c}\text { Confucian } \\
\text { Asia }\end{array}$ & South Asia \\
\hline Intercept & 0.9546 & $(4.4252)^{* * *}$ & $(0.5698)$ & $(2.3490)$ & 0.2491 \\
\hline ROA lagged & $0.8142^{* * *}$ & $0.2355^{* * *}$ & $0.0647^{* * *}$ & 0.0941 & $0.9403^{* * *}$ \\
\hline Size & $(0.0613)$ & $0.3599^{* * *}$ & 0.0627 & $0.1964^{*}$ & 0.0077 \\
\hline Sales growth & 0.0010 & 0.0016 & $0.0078^{* *}$ & 0.0021 & $(0.0031)$ \\
\hline Environmental Score & $(0.0056)^{*}$ & $(0.0125)^{* * *}$ & $(0.0035)$ & $(0.0015)$ & $(0.0015)$ \\
\hline Social Score & 0.00723 & 0.0054 & $0.0060^{* *}$ & $(0.0034)$ & $(0.0019)$ \\
\hline $\begin{array}{l}\text { Corporate Governance } \\
\text { Score }\end{array}$ & 0.0034 & $(0.0072)^{* *}$ & $(0.0072)$ & $0.0079^{* *}$ & $(0.0021)$ \\
\hline R-squared & 0.7828 & 0.2452 & 0.5587 & 0.0565 & 0.9234 \\
\hline Adjusted R-squared & 0.7813 & 0.2360 & 0.5376 & 0.0450 & 0.9217 \\
\hline
\end{tabular}

Note: ${ }^{*},{ }^{*}$ and ${ }^{* * *}$ denote significance levels of $0.1,0.05$ and 0.01 respectively. 


\section{Discussion}

The purpose of this research was to identify how particular CSP pillars influence market value and earnings capabilities of BS and IB\&IS. The aim was also to determine if the CSPCFP link is dependent on the culture associated with bank's country of operations.

\subsection{CSP-CFP link and the type of bank's operations}

Results of this research confirm that banks' performance in subsequent CSP pillars differs when analyzed separately for BS and IB\&IS sub-industries. BS pays more attention to its environmental and social efforts (higher median and average scores than IB\&IS) that indeed might be driven by the industry's types of operations. BS addressable market is represented not only by a business community but also by a great number of individual customers, who increasingly care more about sustainability aspects. In response to their stakeholders needs, banks adjust their strategic choices and disclose more environmentally- and sociallyoriented activities than IB\&IS. By doing so, retail banks seek to improve reputation and gain a competitive edge, especially in the environment of strong competition and limited product differentiation possibilities. In IB\&IS a business case shows that, out of three CS pillars, corporate governance plays a crucial role in shaping a company's reputation. Good corporate governance mitigates investment risks for institutional investors, who represent a great part of IB\&IS target customers. It might explain why IB\&IS outperform BS in its corporate governance performance.

Even though the CSP-CFP link in BS and IB\&IS is not explicit, one may observe some distinctive trends. Corporate Governance has a positive and statistically significant impact on CFP measured with Tobin's q both for BS and IB\&IS. In the long-term, banks from both sectors are financially rewarded for greater transparency of its operations and high-quality governance standards. Interestingly, the impact is around four times bigger for IB\&IS than for BS. Taking into account a greater attention paid by IB\&IS to its corporate governance performance, it seems that IB\&IS has already identified business opportunities related to this aspect. According to the results of this study, in the short-term, improved corporate governance practices do not bring any significant financial returns. Given the results, this research partly confirms the hypothesis that governance performance has a positive impact on CFP in banks (H3), which is in line with the results of Esteban-Sanchez et al. (2017), who also conducted its research on ESG Scores.

In case of environmental and social performance and its effect on CFP, mixed results have been obtained. Environmental activities deteriorate financial performance measured by ROA in BS and reduce Tobin's q in IB\&IS, which confirms the hypothesis that environmental performance has a negative impact on CFP in banks (H1).

In BS, social score reduces Tobin's $\mathrm{q}$ and has no significant impact on ROA, whereas in BS\&IS, it negatively affects ROA and is insignificant in a long-term perspective. The results support the hypothesis that social performance has a negative impact on CFP (H2). In this research, the Social score captures such aspects as workforce, human rights, community impact and product responsibility. The banking industry is highly regulated and its stakeholders might assume that what banks do in the aforementioned social aspects is just enough and 
further developments have no potential to deliver any strategic and financial improvements. Esteban-Sanchez et al. (2017) also found out that product responsibility and better relations with a community have a neutral or even negative impact on CFP. Results of this research contrast with the findings obtained by Simpson and Kohers (2002). However, the authors measured CSP with CRA rating, which reflected mainly bank lending characteristics.

\subsection{CSP-CFP link and bank's cultural affiliation}

There are some evident differences in banks' CSP in cultural regions. Continental Europe is a leader both in environmental and social aspects. It might be backed by a great attention paid to corporate responsibility issues among European Union (EU) citizens (large part of the data sample comes from EU countries). However, it is hard to determine if such performance is stimulated rather by the regions' cultural context or EU regulations aimed at achieving common sustainability targets as there is a thin line between these two factors. A relatively poor environmental and social performance of Anglo-Saxon banks further supports the findings of Chih et al. (2010) that in countries, where investors have strong rights (like in Anglo-Saxon cultures), companies from the financial sector are less CSR-oriented. Low environmental score of Middle East banks might be attributed to poor disclosure of environmental actions by Islamic banks identified by Maali et al. (2006). In terms of Corporate Governance, Anglo-Saxon banks outperform other cultures. A low Corporate Governance score of banks from the Middle East might be also attributable to cultural aspects as the corporate governance concept in Islamic finance differs from the western one (Hasan, 2009). In conclusion, the presented differences in CSP with regard to culture are in line with the findings of existing research (Ringov \& Zollo, 2007; Peng et al., 2014; Ortas et al., 2015; Thanetsunthorn, 2015; Halkos \& Skouloudis, 2017; Gallén \& Peraita, 2017; Adnan et al., 2018).

These results support the hypothesis that the cultural background associated with the bank's country of operations plays a role in the CSP-CFP relationship as this research identifies that each CSP pillar has a different impact on CFP for respective cultures. From a market perspective, an improved environmental performance leads to better financial performance in Anglo-Saxon countries, where banks' average attention to environmental issues is relatively poor. This implicates that among banks operating in the region, any type of better-than-average environmental performance is noticed and positively reflected in investors' expectations. At the same time, in regions where an average environmental score is high, investors do not see value adding potential of increased environmental efforts (i.e. Continental Europe) or even consider them as harmful for CFP (i.e. Confucian Asia and South Asia).

From an accounting-based perspective, further increase of expenditures for costly environmental initiatives (represented in this research with reduced resource use, emissions and improved innovations) does not necessarily boost profitability expressed with ROA. Results of this research suggest that the highest negative impact of environmental scores in Continental Europe, where banks outperform the industry's average. In turn, banks' further environmental activities in the region have more harmful impact than in Anglo-Saxon banks, where environmental performance scores are far below the industry's average. This suggests an inverted $U$ relationship between environmental performance and CFP, which means that 
there might be an optimal level of environmental performance and any deviations lead to lower CFP (Kim \& Oh, 2019; Lankoski, 2000).

From a market perspective, any further investment in social activities of banks from Continental Europe, that achieve the highest average social scores, is perceived as valuedecreasing. At the same time, in Confucian Asia, where the average social score was the lowest, improved social efforts are being noticed by investors and reflected in increased market value. Similarly, to other CSP pillars, this indicates that when all market participants reach a relatively good CSP, additional CS activities are not being rewarded by investors.

In short-term accounting-based perspective, any statistically significant impact of social activities on financial performance have been identified, except for banks from the Middle East, where social activities seem to have positive impact on profitability. Thereby, the conclusions regarding the Middle East are similar to other authors' findings (Mallin et al., 2014). For the Middle East, in the long-term perspective, increased social scores have detrimental impact on the value of banks. These inconclusive results for the region require further investigation that would take into account additional factors connected with specific Islamic finance parameters.

For Corporate Governance, conclusions of this research follow a similar pattern as in other CSP pillars. There is an evidence that there is an optimal, financially rewarding level of corporate governance efforts. Anglo-Saxon banks outperform other regions, which might be attributed to its long tradition of capital-based economy and the following high efficiency of capital markets, where diluted ownership is a common practice. However, with well-developed corporate governance practices, additional improvements do not bring statistically significant impacts on financial results, neither from accounting-based nor from market perspective. In contrast, in Continental Europe, where an average corporate score is lower than for Anglos-Saxon banks, the findings of this research show that investors reward a better-than-average corporate governance performance. Though, an improved corporate governance performance in Continental Europe banks comes as a cost and has a negative and statistically significant impact on ROA.

Other regions, especially Middle East and Confucian Asia, considerably underperform BS' average in the field of Corporate Governance. This may be associated with different corporate governance model for Islamic finance (Hasan, 2009) as well as in Asian countries, where it is often family-based or government affiliated (Tsui \& Scheih, 2003). In Confucian Asia, an improved corporate governance performance has a positive and statistically significant impact on ROA. At the same time, shareholders in this region (i.e. family or keiretsu members and state) react negatively to an increased corporate governance activity, which is reflected in the reduction of Tobin's q.

Based on the diversity of results that this research reveals for regional samples, the hypothesis (H4) that cultural background plays a role in the CSP-CFP relationship in the banking industry has been confirmed.

\section{Conclusions}

The presented study enriches the existing literature on the CSP-CFP link in the Banking Sector and Investment Banking \& Financial Services and fills in the gap related to the moderating effect of culture in this relationship. 
This study confirms the hypothesis that environmental performance has a negative impact on CFP in banks (H1). Its results support the hypothesis that social performance has a negative impact on CFP (H2). The hypothesis that governance performance has a positive impact on CFP in banks (H3) has been partly confirmed. Based on the diversity of results obtained for regional samples, the hypothesis (H4) that cultural background plays a role in the CSP-CFP relationship in the banking industry has been confirmed.

Most prevailing findings in respect to cultural affiliation of banks are that among banks operating in the region, any type of a better-than-average environmental performance is noticed and positively reflected in investors' expectations as in Anglo-Saxon countries. While in regions where an average environmental score is high, investors do not see value adding potential of increased environmental efforts (i.e. Continental Europe) or even consider them as harmful for CFP (i.e. Confucian Asia and South Asia). In respect to corporate governance, results of this research suggest that in Continental Europe, where an average corporate score is lower than for Anglos-Saxon banks, investors reward a better-than-average corporate governance performance, but it comes as a cost and has a negative and statistically significant impact on ROA.

Results of the research also show that out of three CSP pillars (environment, social and corporate governance), corporate governance plays a prevailing role in the banking industry as in both cases of BS and IB\&IS, good corporate governance practices enhance financial results expressed with Tobin's q.

Findings of this research have some implications for practitioners. This research proves that investors reward firms' sustainability performance as exhibited by an increased Tobin's q. In particular, subsequent CSP aspects have statistically significant and positive impact on the figure in regions, where CSP scores are relatively low. This means that in countries where other market players do not pay on average much attention to a particular CSP pillar, banks' managers may increase banks' value through improvement of its CSP.

This study is a subject to certain limitations. Firstly, the sample used in the research covers only listed banks and does not account for privately held entities. As a result, the sample is limited to relatively well-developed capital markets and excludes small and micro finance institutions, which often play a crucial role in supporting sustainable development of local communities. Secondly, the authors of this research used an unbalanced panel and did not account for fixed/random effects that might be present in the data. However, this method has been applied to avoid survivorship bias and gather a large number of observations for both banking industries analyzed in the research as well as each cultural group.

This research was conducted in the period of 2009-2016 which might put in question actuality of results being published in 2020, but the nature of the study is long term, showing long term implications and tendencies in considering CS performance. Therefore, one can notice the universality of conclusions resulting from the study and long term nature of its implications. What is more, the topic of Corporate Social Performance and Sustainability of banks is widely discussed and continuously actual, also in the light of European Union regulation on the establishment of a framework to facilitate sustainable investment that was published on $22^{\text {nd }}$ of June 2020, as Taxonomy Regulation (Regulation EU 2020/852) in the Official Journal of the European Union and entered into force on $12^{\mathrm{ve}}$ of July 2020. Therefore, 
practical implications resulting from this study could be explored in more depth in correspondence with the new regulations.

Future research could investigate further if CSP has a potential not only to improve bank's profitability but also to improve its risk characteristics. This is an important aspect for investors and managers and for the stability of the financial sector.

\section{Acknowledgements}

This paper was prepared based on research financed from the scientific grant for years 20122014 from Polish National Centre of Science no 2011/03/B/HS4/05359 entitled "Impact of CSR activities of the firm on its value".

\section{Funding}

The project is financed by the Ministry of Science and Higher Education in Poland under the programme "Regional Initiative of Excellence" 2019-2022 project number 015/RID/2018/19 total funding amount 10721040.00 PLN.

\section{Author contributions}

TS and KDŻ conceived the study and were responsible for the design and development of the data analysis. AD was responsible for data collection and analysis. TS, KDŻ and AD were responsible for data interpretation. KDŻ and $\mathrm{AD}$ prepared literature review. TS and KDŻ were responsible for final conclusions.

\section{Disclosure statement}

Authors declare that they do not have any competing financial, professional, or personal interests from other parties.

\section{References}

Adnan, S. M., Hay, D., \& van Staden, C. J. (2018). The influence of culture and corporate governance on corporate social responsibility disclosure: A cross country analysis. Journal of Cleaner Production, 198, 820-832. https://doi.org/10.1016/j.jclepro.2018.07.057

Alexander, G. J., \& Buchholz, R. A. (1978). Corporate social performance and stock market performance. The Academy of Management Journal, 21(3), 479-486. https://doi.org/10.5465/255728

Al-Tuwaijri, S. A., Christensen, T. E., \& Hughes, K. E. (2004). The relations among environmental disclosure, environmental performance, and economic performance: A simultaneous equations approach. Accounting, Organizations and Society, 29(5-6), 447-471.

https://doi.org/10.1016/S0361-3682(03)00032-1

Aupperle, K. E., Carroll, A. B., \& Hatfield, J. D. (1985). An empirical examination of the relationship between corporate social responsibility and profitability. The Academy of Management Journal, 28(2), 446-463. https://doi.org/10.2307/256210 
Barth, M. E., Beaver, W. H., \& Landsman, W. R. (1998). Relative valuation roles of equity book value and net income as a function of financial health. Journal of Accounting and Economics, 25(1), 1-34. https://doi.org/10.1016/S0165-4101(98)00017-2

Beck, T., Demirgü-Kunt, A., \& Levine, R. (2010). Financial institutions and markets across countries and over time: The updated financial development and structure database. The World Bank Economic Review, 24(1), 77-92. https://doi.org/10.1093/wber/lhp016

Bohas, A., \& Poussing, N. (2016). An empirical exploration of the role of strategic and responsive corporate social responsibility in the adoption of different Green IT strategies. Journal of Cleaner Production, 122, 240-251. https://doi.org/10.1016/j.jclepro.2016.02.029

Bouma, J. J., Jeucken, M., \& Klinkers, L. (2001). Sustainable banking: The greening of finance. Routledge.

Cheung, A. W. K., \& Roca, E. (2013). The effect on price, liquidity and risk when stocks are added to and deleted from a sustainability index: Evidence from the Asia Pacific context. Journal of Asian Economics, 24, 51-65. https://doi.org/10.1016/j.asieco.2012.08.002

Chih, H. L., Chih, H. H., \& Chen, T. Y. (2010). On the determinants of corporate social responsibility: International evidence on the financial industry. Journal of Business Ethics, 93(1), 115-135. https://doi.org/10.1007/s10551-009-0186-X

Consolandi, C., Jaiswal-Dale, A., Poggiani, E., \& Vercelli, A. (2009). Global standards and ethical stock indexes: The case of the Dow Jones Sustainability Stoxx Index. Journal of Business Ethics, 87(Suppl. 1), 185-197. https://doi.org/10.1007/s10551-008-9793-1

Cornett, M. M., Erhemjamts, O., \& Tehranian, H. (2013). Greed or good deeds: An examination of the relation between corporate social responsibility and the financial performance of U.S. Commercial Banks around the Financial Crisis. Journal of Banking \& Finance, 70, 137-159. https://doi.org/10.1016/j.jbankfin.2016.04.024

Cuesta-González, M., Muñoz-Torres, M. J., \& Fernández-Izquierdo, M. Á. (2006). Analysis of social performance in the Spanish financial industry through public data. A proposal. Journal of Business Ethics, 69(3), 289-304. https://doi.org/10.1007/s10551-006-9091-8

Damodaran, A. (2012). Investment valuation: Tools and techniques for determining the value of any asset. John Wiley \& Sons Inc.

Daszyńska-Żygadlo, K., Słoński, T., \& Zawadzki, B. (2016). The market value of CSR performance across sectors. Engineering Economics, 27(2), 230-238. https://doi.org/10.5755/j01.ee.27.2.13480

Davis, G. F., \& Kim, S. (2015). Financialization of the economy. Annual Review of Sociology, 41, $203-$ 221. https://doi.org/10.1146/annurev-soc-073014-112402

Eccles, R. G., \& Serafeim, G. (2013, May 15). Sustainability in financial services is not about being green. https://hbr.org

Elsayed, K., \& Paton, D. (2005). The impact of environmental performance on firm performance: Static and dynamic panel data evidence. Structural Change and Economic Dynamics, 16(3), 395-412. https://doi.org/10.1016/j.strueco.2004.04.004

Erhemjamts, O., Li, Q., \& Venkateswaran, A. (2013). Corporate social responsibility and its impact on firms' investment policy, organizational structure, and performance. Journal of Business Ethics, 118(2), 395-412. https://doi.org/10.1007/s10551-012-1594-X

Esteban-Sanchez, P., Cuesta-Gonzalez, M., \& Paredes-Gazquez, J. D. (2017). Corporate social performance and its relation with corporate financial performance: International evidence in the banking industry. Journal of Cleaner Production, 162, 1102-1110.

https://doi.org/10.1016/j.jclepro.2017.06.127

EU High-Level Expert Group on Sustainable Finance. (2018). Financing a Sustainable European Economy. https://www.ecb.europa.eu 
European Central Bank. (2010). Beyond ROE - How to measure bank performance. https://www.ecb.europa.eu

European Parliament, \& Council of the European Union. (2020). Regulation (EU) 2020/852 of the European Parliament and of the Council of 18 June 2020 on the establishment of a framework to facilitate sustainable investment, and amending Regulation (EU) 2019/2088. https://eur-lex.europa.eu/eli/reg/2020/852/oj

Fijałkowska, J., Zyznarska-Dworczak, B., \& Garsztka, P. (2018). Corporate social-environmental performance versus financial performance of banks in Central and Eastern European Countries. Sustainability, 10(3), 772. https://doi.org/10.3390/su10030772

Freeman, R. E. (1984). Strategic management: A strategic approach. Pitman.

Friede, G., Busch, T., \& Bassen, A. (2015). ESG and financial performance: aggregated evidence from more than 2000 empirical studies. Journal of Sustainable Finance \& Investment, 5(4), 210-233. https://doi.org/10.1080/20430795.2015.1118917

Fu, L., Parkash, M., \& Singhal, R. (2017). Tobin's q ratio and firm performance. International Research Journal of Appllied Finance, 7(4), 1-10.

Galant, A., \& Cadez, S. (2017). Corporate social responsibility and financial performance relationship: A review of measurement approaches. Economic Research-Ekonomska Istraživanja, 30(1), 676-693. https://doi.org/10.1080/1331677X.2017.1313122

Gallén, M. L., \& Peraita, C. (2017). The effects of national culture on corporate social responsibility disclosure: A cross-country comparison. Applied Economics, 50(27), 2967-2979. https://doi.org/10.1080/00036846.2017.1412082

Garcia-Castro, R., Ariño, M. A., \& Canela, M. A. (2010). Does social performance really lead to financial performance? Accounting for endogeneity. Journal of Business Ethics, 92(1), 107-126. https://doi.org/10.1007/s10551-009-0143-8

Garriga, E., \& Melé, D. (2004). Corporate social responsibility theories: Mapping the territory. Journal of Business Ethics, 53(1-2), 51-71. https://doi.org/10.1023/B:BUSI.0000039399.90587.34

Gonenc, H., \& Scholtens, B. (2019). Responsibility and performance relationship in the banking industry. Sustainability, 11(12), 3329. https://doi.org/10.3390/su11123329

Halkos, G., \& Skouloudis, A. (2017). Revisiting the relationship between corporate social responsibility and national culture: A quantitative assessment. Management Decision, 55(3), 595-613. https://doi.org/10.1108/MD-12-2016-0868

Hasan, Z. (2009). Corporate governance: Western and Islamic perspectives. International Review of Business Research Papers, 5(1), 277-293.

Hofstede, G. (1983). The cultural relatively of organizational practices and theories. Journal of International Business Studies, 14, 75-89. https://doi.org/10.1057/palgrave.jibs.8490867

Hofstede, G. (2011). Dimensionalizing cultures: The Hofstede model in context. Online Readings in Psychology and Culture, 2(1), 8. https://doi.org/10.9707/2307-0919.1014

Hsiao, C. (2007). Panel data analysis-advantages and challenges. Test, 16(1), 1-22. https://doi.org/10.1007/s11749-007-0046-x

Hurley, R. (2014). Understanding trust in banks. International Journal of Bank Marketing, 32(5), 348366. https://doi.org/10.1108/IJBM-01-2014-0003

Jan, A., Marimuthu, M., \& Mat Isa, M. P. B. M. (2019). The nexus of sustainability practices and financial performance: From the perspective of Islamic banking. Journal of Cleaner Production, 228, 703-717. https://doi.org/10.1016/j.jclepro.2019.04.208

Jensen, M. (2002). Value maximisation, stakeholder theory, and the corporate objective function. Business Ethics Quarterly, 12(2), 235-256. https://doi.org/10.2307/3857812 
Jo, H., Kim, H., \& Park, K. (2014). Corporate environmental responsibility and firm performance in the financial services sector. Journal of Business Ethics, 131(2), 257-284. https://doi.org/10.1007/s10551-014-2276-7

Kim, W. S., \& Oh, S. (2019) Corporate social responsibility, business groups and financial performance: A study of listed Indian firms. Economic Research-Ekonomska Istraživanja, 32(1), 1777-1793. https://doi.org/10.1080/1331677X.2019.1637764

Kreiser, P. M., Marino, L. D., Dickson, P., \& Weaver, K. M. (2010). Cultural influences on entrepreneurial orientation: The impact of national culture on risk taking and proactiveness in SMEs. Entrepreneurship Theory and Practice, 34(5), 959-984. https://doi.org/10.1111/j.1540-6520.2010.00396.x

Laguir, I., Marais, M., El Baz, J., \& Stekelorum, R. (2018). Reversing the business rationale for environmental commitment in banking: Does financial performance lead to higher environmental performance? Management Decision, 56(2), 358-375. https://doi.org/10.1108/MD-12-2016-0890

Lankoski, L. (2000). Determinants of environmental profit: An analysis of the firm-level relationship between environmental performance and economic performance [Doctoral dissertation]. https://aaltodoc.aalto.fi/handle/123456789/2510

Lauesen, L. M. (2013). CSR in the aftermath of the financial crisis. Social Responsibility Journal, 9(4), 641-663. https://doi.org/10.1108/SRJ-11-2012-0140

Levine, R. (2005). Finance and growth: Theory and evidence. In P. Aghion \& S. Durlauf (Eds.), Handbook of economic growth (pp. 865-934). Elsevier. https://doi.org/10.1016/S1574-0684(05)01012-9

Lins, K. V., Servaes, H., \& Tamayo, A. (2017). Social capital, trust, and firm performance: The value of corporate social responsibility during the Financial Crisis. The Journal of Finance, 72(4), 1785-1824. https://doi.org/10.1111/jofi.12505

Maali, B., Casson, P., \& Napier, C. (2006). Social reporting by Islamic banks. Abacus, 42(2), 266-289.

Mallin, C., Farag, H., \& Ow-Yong, K. (2014). Corporate social responsibility and financial performance in Islamic banks. Journal of Economic Behavior \& Organization, 103(Suppl.), S21-S38.

https://doi.org/10.1016/j.jebo.2014.03.001

McWilliams, A., \& Siegel, D. (2000). Corporate social responsibility and financial performance: Correlation or misspecification? Strategic Management Journal, 21(5), 603-609. https://doi.org/10.1002/(SICI)1097-0266(200005)21:5<603::AID-SMJ101>3.0.CO;2-3

Michelon, G., Boesso, G., \& Kumar, K. (2013). Examining the link between strategic corporate social responsibility and company performance: An analysis of the best corporate citizens. Corporate Social Responsibility and Environmental Management, 20(2), 81-94. https://doi.org/10.1002/csr.1278

Miras-Rodríguez, M., Carrasco-Gallego, A., \& Escobar-Pérez, B. (2015). Are socially responsible behaviors paid off equally? A cross-cultural analysis. Corporate Social Responsibility and Environmental Management, 22(4), 237-256. https://doi.org/10.1002/csr.1344

Nelling, E., \& Webb, E. (2009). Corporate social responsibility and financial performance: The "virtuous circle" revisited. Review of Quanitative Finance and Accounting, 32(2), 197-209. https://doi.org/10.1007/s11156-008-0090-y

Ortas, E., Álvarez, I., Jaussaud, J., \& Garayar, A. (2015). The impact of institutional and social context on corporate environmental, social and governance performance of companies committed to voluntary corporate social responsibility initiatives. Journal of Cleaner Production, 108(A), 673-684. https://doi.org/10.1016/j.jclepro.2015.06.089

Peloza, J. (2009). The challenge of measuring financial impacts from investments in corporate social performance. Journal of Management, 35(6), 1518-1541. https://doi.org/10.1177/0149206309335188

Peng, C. W., \& Yang, M. L. (2014). The effect of corporate social performance on financial performance: The moderating effect of ownership concentration. Journal of Business Ethics, 123(1), 171-182. https://doi.org/10.1007/s10551-013-1809-9 
Peng, Y.-S., Dashdeleg, A.-U., \& Chih, H.-L. (2014). National culture and firm's CSR engagement: A cross-nation study. Journal of Marketing and Management, 5(1), 38-49.

Porter, M. E., \& Kramer, M. R. (2006). Strategy \& society: The link between competitive advantage and corporatesocial responsibility. Harvard Business Review, 84, 78-92.

Preston, L. E., \& O’Bannon, D. P. (1997). The corporate social-financial performance relationship: A typology and analysis. Business \& Society, 36(4), 419-429. https://doi.org/10.1177/000765039703600406

Ramzan, M., Amin, M., \& Abbas, M. (2021). How does corporate social responsibility affect financial performance, financial stability, and financial inclusion in the banking sector? Evidence from Pakistan. Research in Internation Business and Finance, 55, 101314. https://doi.org/10.1016/j.ribaf.2020.101314

Ringov, D., \& Zollo, M. (2007). The impact of national culture on corporate social performance. Corporate Governance, 7(4), 476-485. https://doi.org/10.1108/14720700710820551

Rodgers, W., Choy, H. L., \& Guiral, A. (2013). Do investors value a firm's commitment to social activities? Journal of Business Ethics, 114(4), 607-623. https://doi.org/10.1007/s10551-013-1707-1

Rowley, T., \& Berman, S. (2000). A brand new brand of corporate social performance. Business \& Society, 39(4), 397-418. https://doi.org/10.1177/000765030003900404

Saeidi, S. P., Sofian, S., Saeidi, P., Saeidi, S. P., \& Saaeidi, S. A. (2015). How does corporate social responsibility contribute to firm financial performance? The mediating role of competitive advantage, reputation, and customer satisfaction. Journal of Business Research, 68(2), 341-350.

https://doi.org/10.1016/j.jbusres.2014.06.024

Schneider, S. C., \& De Meyer, A. (1991). Interpreting and responding to strategic issues: The impact of national culture. Strategic Management Journal, 12(4), 307-320. https://doi.org/10.1002/smj.4250120406

Scholtens, B. (2009). Corporate social responsibility in the international banking industry. Journal of Business Ethics, 86(2), 159-175. https://doi.org/10.1007/s10551-008-9841-x

Shakil, M. H., Mahmood, N., Tasnia, M., \& Munim, Z. H. (2019). Do environmental, social and governance performance affect the financial performance of banks? A cross-country study of emerging market banks. Management of Environmental Quality, 30(6), 1331-1344. https://doi.org/10.1108/MEQ-08-2018-0155

Shen, C. H., Wu, M. W., Chen, T. H., \& Fang, H. (2016). To engage or not to engage in corporate social responsibility: Empirical evidence from global banking sector. Economic Modelling, 55, 207-225. https://doi.org/10.1016/j.econmod.2016.02.007

Shiller, R. J. (2013). Reflections on finance and the good society. American Economic Review, 103(3), 402-05. https://doi.org/10.1257/aer.103.3.402

Simpson, W. G., \& Kohers, T. (2002). The link between corporate social and financial performance: Evidence from the banking industry. Journal of Business Ethics, 35(2), 97-109. https://doi.org/10.1023/A:1013082525900

Siueia, T. T., Wang, J., \& Deladem, T. G. (2019). Corporate social responsibility and financial perfroamcne: A comparative study in the Sub-Saharan Africa banking sector. Journal of Cleaner Production, 226, 658-668. https://doi.org/10.1016/j.jclepro.2019.04.027

Soana, M. G. (2011). The relationship between corporate social performance and corporate financial performance in the banking sector. Journal of Business Ethics, 104(1), 133-148. https://doi.org/10.1007/s10551-011-0894-X

Thanetsunthorn, N. (2015). The impact of national culture on corporate social responsibility: Evidence from cross-regional comparison. Asian Journal of Business Ethics, 4, 35-56.

https://doi.org/10.1007/s13520-015-0042-2 
Tsui, J., \& Shieh, T. (2003). Corporate governance in emerging markets: An Asian perspective. In F. D. S. Choi (Ed.), International finance and accounting handbook. John Wiley \& Sons Inc.

Waddock, S. A., \& Graves, S.B . (1997). The corporate social performance-financial performance link. Strategic Management Journal, 18(4), 303-319. https://doi.org/10.1002/(SICI)1097-0266(199704)18:4<303::AID-SMJ869>3.0.CO;2-G

Wang, Y., \& Berens, G. (2015). The impact of four types of corporate social performance on reputation and financial performance. Journal of Business Ethics, 131(2), 337-359. https://doi.org/10.1007/s10551-014-2280-y

Zyznarska-Dworczak, B. (2018). The development perspectives of sustainable management accounting in Central and Eastern European countries. Sustainability, 10(5), 1445.

https://doi.org/10.3390/su10051445 